\title{
Transatlantica
}

Revue d'études américaines. American Studies Journal

2 | 2014

Aesthetics of Theory in the Modern Era and Beyond / Photographie documentaire

\section{An Interview with Bobbie Ann Mason}

\section{Candela Delgado Marín}

\section{(2) OpenEdition}

1 Journals

Electronic version

URL: https://journals.openedition.org/transatlantica/7141

DOI: 10.4000/transatlantica.7141

ISSN: $1765-2766$

Publisher

Association française d'Etudes Américaines (AFEA)

\section{Electronic reference}

Candela Delgado Marín, "An Interview with Bobbie Ann Mason", Transatlantica [Online], 2 | 2014, Online since 09 March 2015, connection on 01 February 2023. URL: http://journals.openedition.org/

transatlantica/7141 ; DOI: https://doi.org/10.4000/transatlantica.7141

This text was automatically generated on 1 February 2023.

\section{(c) (i) () $\Theta$}

Creative Commons - Attribution-NonCommercial-NoDerivatives 4.0 International - CC BY-NC-ND 4.0 https://creativecommons.org/licenses/by-nc-nd/4.0/ 


\title{
An Interview with Bobbie Ann Mason
}

\author{
Candela Delgado Marín
}

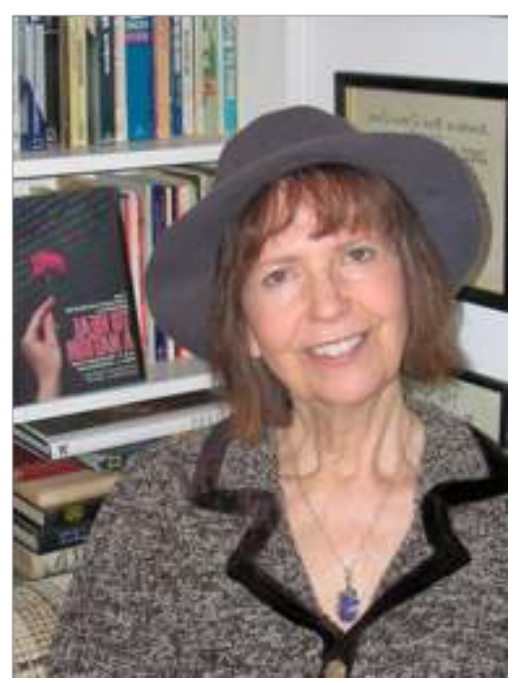

Image Copyright (c) by LaNelle Mason

Bobbie Ann Mason is a writer, born and raised in Mayfield, in western Kentucky. In her childhood, the discovery of mystery novel series, such as The Bobbsey Twins or Nancy Drew, ${ }^{1}$ and novels such as Louisa May Alcott's Little Women, triggered a curiosity for lifestyles that seemed unachievable in her hometown. Her young self soon felt the limitations of the place : "It was an isolated corner of Kentucky, far from any city. My parents encouraged me to read, but there were few books available, certainly nothing called literature" (Alger, 2012, Pif Mafazine). Ms. Mason was determined to pursue an educational path, which gradually took her away from the South. She earned her B.A. in English at the University of Kentucky in 1962, but she later moved to Binghamton, New York, where she completed an M.A. from Harpur College (now The State University of New York at Binghamton) in 1966. And she remained in the North to pursue her Ph.D. at the University of Connecticut (1972). Since college, her readings grew with her 
academic career ; already in university, she enjoyed the works of Hemingway, Salinger, Fitzgerald and Thomas Wolfe.

2

Bobbie Ann Mason's dissertation on Vladimir Nabokov's Ada was published (Ardis, 1974), but she never found comfort in teaching jobs and she soon distanced herself from academia. However, she was always motivated by journalism and fiction. During her university years she wrote for the Kentucky Kernel, and Gurney Norman ${ }^{2}$ encouraged her to take a creative-writing course with writer Robert Hazel. ${ }^{3}$ By then, Ms. Mason states, she knew she was destined to become a fiction writer (Pokrass, 2012, New World Writing). When Ms. Mason moved to New York, she worked on a magazine, and later as an assistant professor at Mansfield University, in Pennsylvania, from 1972-1979. But, eventually, Joanna Price ${ }^{4}$ tells us in her book on the author (4), she stopped teaching to devote herself fulltime to writing, starting to submit stories to The New Yorker. After having been rejected many times, yet receiving encouragement from editor Roger Angell (Mason, 1997, The Missouri Review), in 1980, Ms. Mason's story "Offerings" was published. Bobbie Ann Mason has continued to this day writing for the magazine. With this, Bobbie Ann Mason's writing career took off. She published her first collection of short stories Shiloh \& Other Stories, which won the P.E.N/ Hemingway Prize, in 1982. The collection shows a writer from the South, a Southern writer, but one that left the South behind to gain perspective, as she moved back to Kentucky in 1990 : "I think my exile in the North gave me a sense of detachment, a way of looking in two directions at once. It's an advantage" (Mason, 1997, The Missouri Review). Regardless of her literary studies and experiences in big Northern cities, she claims: "my real sources, the influences that were of value to me later as a writer, were the natural world - the infinite sensory details of growing up on a farm - and the language of country people. No amount of reading could have given me those treasures" (Alger, 2012, Pif Magazine)

3 Ms. Mason was a "writer-in-residence" at the University of Kentucky for ten years (2001-2011). She is a member of the Authors Guild, PEN, and the Fellowship of Southern Writers, and she is a former Guggenheim Fellow (1983) and National Endowment for the Arts grant award recipient (1983). The author was also honored in 2010 with The Appalachian Writer's Heritage Award. She has published four more short story collections, Love Life (1988), Midnight Magic (1998), Zigzagging Down a Wild Trail (2001) and Nancy Culpepper (2006); a memoir that was a finalist for the Pulitzer Prize, entitled Clear Springs (1999) ; and five novels, In Country (1985), Feather Crowns (1993), Spence + Lila (1998), An Atomic Romance (2005), and her latest, The Girl in the Blue Beret (2011), which has received the Kentucky Book Award (2012). The novel was inspired by her father-inlaw's experience as a WWII Allied pilot, who was shot down over Belgium in January 1944. The novel, however, is fiction, and relates the story of Marshall Stone. Bobbie Ann Mason says : "It was a challenge, and no book I've written has involved me so deeply" (Mason, 2012, Random House Reader's Circle). Since the publication of the novel, Ms. Mason has published a number of short stories in different magazines and journals: "Dance with Me" (July, 2013) in Good Housekeeping Magazine, "Clubbing" (December, 2013) and "The Face Lady" (February, 2013) in New World Writing, "The Horsehair Ball Gown" (Spring, 2013) in VQR, as well two collaborative pieces with flash-fiction writer Meg Pokrass, "Tweeting War and Peace" (October, 2012) in Flash Fiction and "Whale Love" (August, 2013) in the online magazine The Nervous Breakdown. Ms. Mason's most recent 
publications are the story "Rendering" (April, 2014) in The Green Mountains Review, "Four Short Pieces" in New World Writing (August 2014) and the essay "Reading Between the Lines" again in VQR (Spring 2014). Her newest story is entitled "Ready" in the aforementioned The Nervous Breakdown (November 2014); this last piece, as with much of her latest creations, was written with humorous intent.

4 Bobbie Ann Mason is one of the finest contemporary Southern writers, and she is internationally recognized. Both in her short fiction and novels, her writing reveals the deepest respect for her roots and curiosity for the lives and landscapes that surround her. Although her style is simple, Ms. Mason creates complex characters with a balanced caring detachment. The language of the narrators and the speeches in dialogues contain the musicality and rhythm that can only emerge from a keen observer and listener. Bobbie Ann Mason includes both common verbal expressions with beautifully rendered tropes that portray a combination of the earthy details of everydayness, the presence of popular culture, the ironic humor occurring in tragic moments, the grotesque aspects of urban and rural decay, and, equally, the delicacy and elegance of Nature. Her characters are pragmatic but frequently allow themselves to indulge in imagination, and with them, the reader experiences both visions of Bobbie Ann Mason's fictional world.

CDM : New Yorker author Hannah Rosefield wrote a piece ("No More Questions", 2014) this January reflecting on the struggle or nuisance interviews may represent for writers. She reported that in 1904, Henry James said in his first interview : "One's craft, one's art, is his expression, not one's person." And Joyce Carol Oates claimed earlier this year that a "writer's life is in his work, and that is the place to find him." How do you approach interviews?

BAM : What is difficult about an interview.... A writer spends weeks and months and years working with words, trying to get them into a final shape that works, so that the whole can't be easily broken apart, so that the words chosen are exactly the right ones. Then the writer, who is maybe not a talker, is suddenly on TV and expected to talk off the top of her head and make sense! The transition is startling. Also, the writer may be expected to be articulate, to talk in confident analytical terms, while writing fiction is so different! It is more like singing a song while swimming underwater.

CDM : And yet I find your answers literary, as well as analytical. Your language seems to be unconditionally linked to the musicality of fiction. Don't you feel that interviews for writers are created to receive answers that maintain the tone of the author's fiction? What are the emotions that you relate to the image you just described, "singing a song while swimming underwater" ?

BAM : The approach of the literary critic is so different from that of the fiction writer. The critic wants to explicate and comprehend what the writer may not be of a disposition to explain. The writer is not thinking in those terms. The metaphor above draws from the mystery and the fear of creation and the music that is its aim.

CDM : In your latest novel, The Girl in the Blue Beret, Marshall Stone, an American WWII veteran who was a B-17 bomber pilot, now a retired widower in his 60 s, revisits France in the quest to find the members of the French Resistance that helped him and other Allied aviators escape occupied Europe once his plane was shot down in Belgium. One of the people he is most keen to locate is Annette, the young girl from the Resistance, who wore a blue beret to be recognized and whose family hid him until he could be safely transferred to Spain. In the novel, Annette's family is betrayed and they are imprisoned in labor camps. 
Annette and her mother survive.

You visited Chojna, in Poland, in September 2013 because the WWII labor camp, where five hundred women worked in inhuman conditions to build an airfield runway, was located there. The trip could be seen as a follow-up to the publication of the novel. Michèle MoëtAgniel is your real model for the girl in the blue beret. You tried to contact her in 2008 because you had once seen a picture of her with your father-in-law, in 1993 at a reunion of Allied aviators and the Europeans who had helped these airmen escape from the Germans (Mason, 2013, The New Yorker). You eventually found her and she agreed to meet you. During your conversation, before visiting Chojna, you showed her photos of the abandoned airfield, where she was forced to work. Michèle, in her eighties now, stared for a long time at one of the pictures of the runway. In your notes from the encounter you describe how her eyes focused on a point "where flowers were growing through the cracks in the pavement." You add: "Finally she [Mrs. Moët-Agniel] said, 'I built that'." This report of such a moving anecdote marks for me the clear difference between your novel and history. I would really appreciate hearing your take on the fine line between fiction that deals with history and the study of a historian.

BAM : Although they may want to discover and present the fascinating story within their subject, historians don't normally take the liberties fiction writers do. Fiction writers are generally dedicated to showing a kind of truth that the known facts alone might not reveal. What was it like to be a bicycle courier in World War II ? How did it feel to fly a bombing mission? In realistic fiction, within certain boundaries of historical fact, the writer is free to invent characters, descriptions, plots. On the other hand, my friendship with Michèle Agniel has provoked profound thoughts and feelings about some things that actually happened. And that, in turn, is different from reading fiction.

CDM : Writer Daniel Swift in his review of the novel in The New York Times states the book is a work of "remarkable empathy" ("A War World II Veteran Revisits his Saviors", 2011). How does it affect your conception of the story when research intertwines with the establishment of personal relationships, when the sources being investigated are loaded with emotions?

BAM : The Girl in the Blue Beret was an unusual venture for me because it was inspired by real people and their stories. Normally, I am not restrained by any desire to stick to someone's story. It is much easier to invent. But in this case, not only did some real stories draw me into the subject, but I began to feel a deeper commitment to doing justice to their stories. Still, that did not mean I followed them literally. Rather, it meant that I felt motivated to go as deeply, imaginatively, as I could into the possibilities of their history.

CDM : Present and past frequently merge in your novels and short stories. At times, recollections seem to assail the characters. This is a constant in The Girl in the Blue Beret, as it was for the Vietnam veteran Emmett in your novel In Country. You explained that the main character in your latest novel, Marshall, had been avoiding the past, and during his European quest, memories start to come forth, at times, when he least expects it (Bloom, 2012, The Art of Word Making). How do you interweave the present and remembrances? Do you approach the representation of traumatic war memories with a specific technique?

BAM : It was the interplay of two narrative lines-the present, 1980, and the past, 1944. Incidents in the present triggered memories of the past. Psychologically, it was fairly simple. Not all the memories would come at once. For instance, the memories of Marshall's B-17 being shot down are doled out from time to time-for narrative 
suspense-before Marshall can face the full impact of the crash-landing. So the reader experiences it gradually, and likewise Marshall slowly comes to term with his memories.

CDM : You state the following in the "Introduction" to your short story collection Midnight Magic: "Like me, these characters are emerging from a rural way of life that is fast disappearing, and they are plunging into the future at a rapid saunter, wondering where they are going to end up ... I am excited to meet them at a major intersection" (xii). Much has been written about the concept of the Post-Southern reality, an ever-changing simulacra of what the South used to be. As a writer, how do you work with this "intersection" as the setting, with the Post-Southern everydayness?

BAM : I don't think about it in these broad terms. I'm an observer of detail. I notice what people have in their shopping carts at the grocery, what they are saying when I overhear them, what they're wearing, what kinds of jobs they have. The particulars going on in a character's life reveal this larger concern. You can't address "intersections" and "simulacra" straight on. You have to hear a character saying, "It's amazing that I have strong feet, coming from two parents that never had strong feet at all." I actually overheard that, and it entered my story "Shiloh". That sentence contains so much. It is the sound of it, the attitude.

$\mathrm{CDM}$ : Is it then from the language, the chosen words, and the details being described that the current South and its features spring up ? How do you think a reader unfamiliar with the American South could read, and pick up on, this subtle contextual information?

BAM : Actually, I think it would be very difficult, without an intimate knowledge of the sounds and nuances of the language. Sometimes I think that what is most important to me about the sound of the prose is just not something that will be noticed! Even in English.

CDM : History, tradition and legacy are essential concepts in your writings. Your characters are not completely disentangled from their roots. In your story "The Heirs", the narrator explains how the main character appreciates a box of her family's letters, pictures and a stick of dynamite. The objects, somehow, narrate her family's past. There is a respectful approach to the materiality of memories: "Nancy saw herself in this group of people, lives that had passed from the earth as hers would too. She felt comforted by the thought of continuity, even if a stick of dynamite could be called an heirloom" (Nancy Culpepper, 202). Do you play with objects as somehow speaking for your characters?

BAM : I don't really know how to answer that. I'm usually dealing with objects like sticks of dynamite on a fairly literal level. This is what makes them work for the reader ultimately as symbols or narrative objects or whatever. If you get the surfaces rights, in the right combinations, at the right angle, then they will embody in the larger story those themes, symbols, concepts, etc., that entertain the classroom.

CDM : When observing these details that surround you, do objects ever work as triggers for stories? How?

BAM : Very often it is an image of some sort that sparks the inspiration for a story. That stick of dynamite found in a box of letters may very well have been the trigger for that story. In the opening of "Shiloh", Norma Jean is lifting weights. The novel In Country was initially inspired by the sight of a couple of teenagers selling flowers on a street corner, but that scene was eventually dropped.

CDM : In the article "Honoring her Fathers" (Mason, 2011, Book Reporter) you narrate your reconciliation with the South by re-establishing a bond with your father. I was intrigued by your choice of the verb "to gravitate" in order to create the metaphor: 
But in the last years of his life we found common ground as I gravitated back to the land. We shared a love for animals. He liked to have a small dog with him in his car, so they could go motivating down the road listening to Chuck Berry. I got my musical tastes from him.

For me, your use of the word "gravitate" also suggests gravitas in the sense of "dignity." How do you convey this Southern gravitas, which is still often ignored in cultural representations and the media?

BAM : "Gravitate" is from modern Latin "gravitare," to move, from Latin gravitas, weight. In that quote, I was more concerned with the echo of "gravitating" in the word "motivating," a word Chuck Berry uses in his 1950s song "Maybellene." ("As I was motivatin' over the hill, I saw Maybellene in her Coupe de Ville.") Motivating implies purpose, and Chuck Berry's creative misuse of the word suggests he is motoring purposefully-with a strong motive! Maybelline has been untrue and he is speeding after her. I don't know if you can get gravitas out of that sense of vitality and purpose. And humor. As for my father, I'd think of humor before I'd think of gravitas.

CDM : Female friendships are a constant in your writing. In the story "Bumblebees", three women have decided to move to a farm together and work and live off the land. You portray their intimacy in the following way: "With the three of them cooped up, trying to stay out of each other's way, Barbara feels that the strings holding them together are taut and fragile, like the tiny tendrils on English-pea vines, which grasp at the first thing handy" (Love Life, 109). Three women confront their fears within the narrow limits of the house, creating a sense of tension and annoyance, simultaneously with a strong loving bond. How do you recall your own experience of living in a house full of grandmothers, mothers and sisters?

BAM : I don't remember it exactly that way, and "Bumblebees" is fiction. I grew up with one grandmother, one mother, two younger sisters. My grandmother and mother were always working with food. And they made our clothes. I wanted to read books and escape farm life! That was the tension for me, but I've imagined these women in "Bumblebees" who choose that life.

CDM : But you eventually moved back to Kentucky, would it be fair to say that you also "chose" that life after having left it behind?

BAM : Not entirely. I had escaped the narrow confines of the cultural and economic expectations and I was able to come back on my own terms.

CDM : You have recently published short humor pieces in your collaborations with Meg Pokrass, like "Leda and the Crane Daddy" (Mason and Pokrass, 2012, Fictionaut), which combine that humor with political criticism. How did this project emerge? Do you feel a stronger need to become political in your latest writings?

BAM : Meg did an interview with me for an online journal called Fictionaut. We discovered we shared a sense of humor and that led to a longer interview for New World Writing. Then we started writing a few things together just for fun. I didn't see anything particularly political in those. Was there?

CDM : I read political satire in the references to Putin's stunts as a "savior" and the ironic references to "red" and communism, attitudes in American foreign policies, health insurance and the luxurious life of those in power. Could the wry wit of the piece make the reader laugh as well as ponder on the oddities of current affairs?

BAM : The piece was topical, taking place during the last election. It was making fun, not necessarily provoking deep thought! Well, there were oddities to be sure.

CDM : I am really interested in the volume Missing Mountains: We Went to the Mountaintop But It Wasn't There (2005), where you contributed an article denouncing the disastrous environmental effects of mountaintop mining. Here you show your commitment to the 
preservation of the American landscape. Previously in 2000 you published the article "FallOut: Paducah's Secret Nuclear Disaster" in The New Yorker, which conveys a disappointment with Kentuckians for their passive attitude towards the poisonous presence of the nuclear plant in their land. You generally praise the resilience of farmers but also mentioned then that the lack of drive to fight for their rights was not surprising "in an agricultural region, where farmers forgive the forces they cannot control." Do you ever reflect this attitude in your characters?

BAM : Yes, I would say so. My novel An Atomic Romance features a man who works at a uranium enrichment plant, within a culture of denial. For the nuclear-fuel workers, it is a matter of livelihood. It is too scary, too uncomfortable, for them to ask too many questions, so they close their eyes to the dangers.

CDM : How do they reconcile their instinct of survival and resilience with their love for the soil and landscape that might be endangered?

BAM : I don't know about those folks, but I think that often people in denial about something can find convenient rationalizations, and often they seize on wrongheaded beliefs that prevent them from having to confront what they fear.

CDM : Talking about your novel An Atomic Romance, is it true that Salvador Dalís Atómica Melancólica ${ }^{5}$ (1945) served as an inspiration for it ? When did you come across the painting and what was your reaction to it? The connection of these two artistic pieces became significant for me in reading the following words about the main character Reed, the engineer with a passion for astronomy: "He tried to imagine what an astronaut would see, peering down on that patch of green earth with its gray scar, the earth still steaming from its little wound" (50-51). Are we peering through those scars in Dali's painting?

BAM : The painting wasn't an inspiration. It was just a pleasing discovery that seemed to corroborate the impulse of my novel or reflect its concerns. I don't remember when I became aware of it, certainly when I was well into the writing of the novel. I tried to see the painting in 2005 in Madrid but it was not on display.

CDM : In April 2012 you read a poem from Wendell Berry's Leavings entitled "VI" in the National Endowment for the Humanities ${ }^{6}$ program at the Kennedy Center for the Performing Arts. Berry was selected by the NEH to give the Jefferson Lecture, a prestigious honor granted by the federal government for distinguished intellectual achievement in the humanities. I find a strong connection between his lines and your work. Allow me to quote Berry:

I will be leaving how many beauties overlooked?

A painful Heaven this would be, for I would know

by it how far I have fallen short. I have not

paid enough attention, I have not been grateful

enough. And yet this pain would be the measure

of my love. In eternity's once and now, pain would

place me surely in the Heaven of my earthly love. $(2010,71)$

Could you tell us why you chose this poem and what it means to you?

BAM : I did not choose the poem. It was chosen by the program planners, perhaps with the approval of Wendell Berry. I was merely asked to read it aloud at the program. I do like the poem and agree with its joyous embrace of the delights in this world, as opposed to those promised by heaven. Yes, heaven would be this world, with all my favorite pets, and my family still here.

CDM : LATER IN THE YEAR, IN your speech "Don't Live a Throwaway Life" at the 2012 Earth Day Awards Ceremony for the Kentucky Environmental Quality Commission, you declared:

"GROWINg UP ON A FARM TAUght ME TO BE OBSERVANT, TO PAY ATTENTION TO EVERY DETAIL IN FRONT OF ME - A BIRD FEATHER, A FUNNY BUg, A PATCH OF MOSS. THIS IS A 
HABIT OF MIND I HAVE FOUND INDISPENSABLE FOR WRITINg fICTION, WHICH AFTER ALL IS LIKE PIECINg QUILTS FROM SCRAPS, SOMETHINg | learned from my grandmother" (Mason, 2012, Courier Journal). Could you elaborate on how being observant influences your creative process?

BAM : For me, stories are made out of tiny details stitched together. I consider that growing up on a farm provided me with the richest textures and sensations as well as a solid grounding in the natural world. I didn't have many books when I was growing up, but I did have bugs and chickens and blackberries and cows and an infinitely complex world to explore.

CDM : It might be in the complexity of a simple life, a rural life, where elements of the landscape sometimes articulate intimate emotions for people. Christie, the mother of quintuplets in the turn-of-the-last-century novel Feather Crowns, dreads the death of her babies. She observes one of them: "It was the one that made Christie see the dark winter branches of a rained-soaked tree, with the deep blue sky coming through from behind. She heard him cry -a strong, healthy cry" (88).

Is Christie decoding nature, with the sharpest skills, as if it were a book to be read?

BAM: I seem to recall that in that novel Christie associates specific imagery, particular sensations, with each of her five babies. It is a blending of the senses and feelings. She is attuned to the natural world and her babies are part of it.

CDM: I would like to talk to you about a paradox I have myself encountered in reading Southern literature and that is related to this contemplative attitude we have been discussing and the idea of storytelling in the South. Eudora Welty wrote in her essay "Place and Time: The Southern Writer's Inheritance":

It is nothing new or startling that Southerners do write-probably they must write. It is the way they are: born readers and reciters, great document holders, diary keepers, letter exchangers and savers, history tracers-and, outstaying the rest, great talkers. Emphasis in talk is on the narrative form and the verbatim conversation, for which time is needed. Children who grow up listening through rewarding stretches of unhurried time, reading in big lonely rooms, dwelling in the confidence of slow-changing places, are naturally more prone than other children to be entertained from the first by life and to feel free, encouraged, and then in no time compelled, to pass their pleasure on. They cannot help being impressed by a world around them ... (163)

This paragraph summarizes the primary contradiction I find in Southern literature: characters are storytellers and yet, at the same time, they are introverts. When you are creating a character, do you find any compatibility between these two traits?

BAM : Well, these two traits can't be true of every character, and I can't say that I have given this idea any thought in my own writing. I don't recognize much of what Eudora Welty says about "great talkers." I'm not a natural storyteller, I didn't grow up with a traditional storytelling Southern background, and my characters are probably mostly introverts. What affected me was the sound of talking, perhaps because it was not a constant. The sounds came out of silence, so they were surprises -noticeable, memorable. At any rate, most of my characters are restrained in their speech and often reveal more by saying less. In many situations it is difficult for them to speak, and that is a tension that is more interesting to me than listening to the storyteller who never shuts up.

CDM: Without imposing literary labels on your writing, and as a closing remark, are there any writers, storytellers, that you feel close to?

BAM : An author I feel especially close to is Alice Munro because our backgroundsgrowing up on farms-were so similar. Reading her autobiographical works is especially interesting to me. Of course her fiction is so widely adored. I can only regard it in stunned admiration. My favorite writer is Vladimir Nabokov, the word 
wizard. And his life was worlds away from mine. His writing genius too, but I do feel I share something of his sensibility. And we were both exiles.

$\mathrm{CDM}$ : What are you currently reading?

BAM : Right now I'm reading Anna Karenina (1877). And before that I read a nice novel by Judy Troy, The Quiet Streets of Winslow (2014), and Frederick Barthelme's new novel There Must Be Some Mistake (2014). Recently I also read Sweet Tooth (2012) by Ian McEwan.

CDM : Would you like to finish up our interview by commenting on your current work? What have you been focusing on and devoting your days to lately?

BAM : I have been writing stories, all of which either take place in California or have some link to California. I am imagining a book called "California Stories". Some of the stories are very short-forays into flash fiction. I have three flash pieces in a special flash-fiction issue of Frederick Barthelme's online journal, New World Writing. And I may be doing some more collaboration with Meg Pokrass. She tickles my funny bone.

CDM : Thank you very much, Ms. Mason. Please, keep your pen close to the page for our delight.

BAM : Thank you for bearing with me.

\section{BIBLIOGRAPHY}

Work Cited :

ALFER, Derek, “Bobbie Ann Mason Interviewed by Derek Alger”, Pif Magazine, July 2012, http://www.pifmagazine.com/2012/07/bobbie-ann-mason/ (last accessed on $3^{\text {rd }}$ April, 2014). BERRY, Wendell, Leavings : Poems, Berkeley, Counterpoint, 2010.

BLOOM, Lary, "Bobbie Ann Mason, Time Traveler", The Art of Word Making, July 2012, http://larybloom.net/2012/07/01/bobbie-ann-mason-time-traveler/

(last accessed on $4^{\text {th }}$ April, 2014).

JOHANNSEN, Kristin, Bobbie Ann MASON and Mary Ann TAYLOR-HALL Eds., Missing Mountains : We Went to the Mountaintop but it Wasn't There, Nicholasville, Wind Publications, 2005.

MASON, Bobbie Ann, The Girl Sleuth : On the Trail of Nancy Drew, Judy Bolton and Cherry Ames, Athens, University of Georgia Press, 1975.

---, Shiloh \& Other Stories, New York, The Modern Library, 1982.

---, In Country, London, Flamingo, 1985.

---, Love Life : Stories, New York, Harper \& Row, 1988.

---, "Interview with Bobbie Ann Mason", The Missouri Review, Issue 20.3, "The Search After Happiness", Fall 1997, http://www.missourireview.com/archives/bbarticle/interview-withbobby-ann-mason/ (last accessed on $5^{\text {th }}$ April, 2014). 
---, Clear Springs : A Memoir, New York, Random House, 1999.

---, "Fall-Out : Paducah's Secret Nuclear Disaster", The New Yorker, $10^{\text {th }}$ January 2000, 30-36.

---, Zigzagging Down a Wild Trail, New York, Random House, 2001.

---, "Dance with Me”, Good Housekeeping, Hearst Magazines UK, vol. 257, Issue 1, July 2003, 159.

---, An Atomic Romance : A Novel, New York, Random House, 2005.

---, Nancy Culpepper : Stories, New York, Random House, 2006.

---, The Girl in the Blue Beret, New York, Random House, 2011.

---, “Honoring her Fathers", The Book Report, June 2011, http://www.bookreporter.com/blog/ 2011/06/14/bobbie-ann-mason-honoring-her-fathers (last accessed on 5th April, 2014)

---, “Don’t Live a Throwaway Life”, Courier Journal, Courier-Journal Media, May 2012,

http://archive.courier-journal.com/article/20120506/OPINION04/305060056/bobbie ann mason farm life (last accessed on $4^{\text {th }}$ April, 2014).

---, “A Letter from Bobbie Ann Mason, Author of The Girl in the Blue Beret", Random House Reader's Circle, July 2012, http://www.randomhouse.com/rhpg/rc/2012/07/16/a-letter-from-bobbie-annmason-author-of-the-girl-in-the-blue-beret (last accessed on $5^{\text {th }}$ April, 2014).

---, and Meg POKRASS, “Whale Love”, The Nervous Breakdown, August 2012, http://

www.thenervousbreakdown.com/tnbfiction/2013/08/tnb-original-fiction-whale-love-by-bobbieann-mason-meg-pokrass/ (last accessed on $3^{\text {rd }}$ April, 2014).

---, and Meg POKRASS, "Tweeting War and Peace”, The

Nervous Breakdown, October 2012,

http://www.thenervousbreakdown.com/mpokrass/2012/10/tweeting-war-and-peace-withbobbie-ann-mason/ (last accessed on $3^{\text {rd }}$ April, 2014).

---, and Meg POKRASS, “Leda and the Crane Daddy", Fictionaut, October 2012, http:// fictionaut.com/stories/meg-pokrass/tweeting-war-and-peace-by-bobbie-ann-mason-and-megpokrass--3 (last accessed on 4th April, 2014).

---, “The Horsehair Ball Gown”, The Virginia Quarterly, Spring 2013,

http://www.vqronline.org/fiction/horsehair-ball-gown (last accessed on $4^{\text {th }}$ April, 2014).

---, “The Real Girl in the Blue Beret”, The New Yorker, May 2013,

http://www.newyorker.com/books/page-turner/the-real-girl-in-the-blue-beret (last accessed on $25^{\text {th }}$ May, 2013).

---, “Clubbing”, New World Writing, Fall 2013,

http://newworldwriting.net/back/fall-2013-3/bobbie-ann-mason/

(last accessed on $4^{\text {th }}$ April, 2014).

---, “The Face Lady", New World Writing, Winter 2014, http://newworldwriting.net/back/ winter-2014-3/bobbie-ann-mason-2/ (last accessed on $20^{\text {th }}$ February, 2014).

---, “Rendering”, Green Mountain Review, vol. 27, No. 1, Spring 2014.

---, "Four Short Pieces", New World Writing, Spring, 2014.

http://newworldwriting.net/spring-2014/bobbie-ann-mason/ 
(last accessed on $28^{\text {th }}$ November, 2014).

---, "Reading Between the Lines", VQR, vol. 90, No. 2, Spring 2014, http://www.vqronline.org/ essays-articles/2014/03/reading-between-lines (last accessed on $8^{\text {th }}$ October, 2014).

---, "Ready", The Nervous Breakdown, November 2014, http://www.thenervousbreakdown.com/ tnbfiction/2014/11/tnb-original-fiction-ready-by-bobbie-ann-mason/

(last accessed on $28^{\text {th }}$ November, 2014).

POKRASS, Meg, “Bobbie Ann Mason Interviewed by Meg Pokrass”, New World Writing, Fall 2012, http://newworldwriting.net/back/fall-2012-2/bobbie-ann-mason/ (last accessed on $4^{\text {th }}$ April, 2014).

PRICE, Joanna, Understanding Bobbie Ann Mason, Columbia, University of North Carolina, 2000.

ROSEFIELD, Hanna, “No More Questions", The New Yorker, January 2014, http://

www.newyorker.com/books/page-turner/no-more-questions?

utm_source=tny\&utm_campaign=generalsocial\&utm_medium=facebook (last accessed on $6^{\text {th }}$ April, 2014).

SWIFT, Daniel, “A World War II Veteran Revisits His Saviors”, The New York Times. Sunday Book Review, July 2011, http://www.nytimes.com/2011/07/24/books/review/the-girl-in-the-blueberet-by-bobbie-ann-mason-book-review.html (last accessed on $6^{\text {th }}$ April, 2014).

WELTY, Eudora, "Place and Time : The Southern Writer's Inheritance", Occasions : Selected Writings by Eudora Welty, Ed. Pearl Amelia McHaney, Jackson, University Press of Mississippi, 2009.

\section{NOTES}

1. The Bobbsey Twins and Nancy Drew were published respectively under the pseudonyms, Laura Lee Hope and Carolyn Keene, used by the Stratemeyer Syndicate, which was a children's book packager. It was founded in 1905 by Edward Stratemeyer, who hired ghostwriters to create a successful series of adventure stories. These were based on three-page plots Stratemeyer wrote himself and handed to his staff writers. He published over 700 hundred books under approximately 70 pseudonyms (Mason, 1975, 8).

2. To learn more about Prof. Norman, please visit the following Website: https:// english.as.uky.edu/users/gnorman

3. Author John Kuehl wrote a piece to remember Robert Hazel in VQR literary Journal in Spring of 1994. It can be found here:

http://www.vqronline.org/threnody-my-name

4. To learn more about Dr. Price, please visit the following Website: http:// www.ljmu.ac.uk/HSS/114957.htm

5. A picture of the painting can be seen in the Website of the Museo Nacional Centro de Arte Reina Sofía: http://www.museoreinasofia.es/en/collection/artwork/atomica-melancolicamelancholic-atomic

6. A video recording of the ceremony, including Mason's reading, can be watched in the streaming media Website TV Worldwide:

http://events.tvworldwide.com/Events/NEH2012JeffersonLecture.aspx?

VID=events\%2Fneh\%2F120423_NEH_Jefferson_Lecture_KennedyCtr.flv\&CAP=events\%2Fneh\%2F120423_NEH_Jefferson_Lecture_Kenned 
INDEX

Subjects: Reconnaissances

\section{AUTHOR}

CANDELA DELGADO MARÍN

University of Seville 